\title{
Removal of Arsenic from Wet Scrubbing Wastewater
}

\author{
Francesco Ferella \\ Department of Industrial Engineering, Information and Economics (DIIIE) \\ University of L'Aquila, Monteluco di Roio, 67100 L'Aquila, Italy \\ Tel: 39-086-243-4238Ｅ-mail: francesco.ferella@univaq.it
}

Ida De Michelis, Francesco Vegliò

Department of Industrial Engineering, Information and Economics (DIIIE)

University of L'Aquila, Monteluco di Roio, 67100 L'Aquila, Italy

Received: September 3, 2016

Accepted: October 12, 2016

doi:10.5296/emsd.v5i2.10187

URL: http://dx.doi.org/10.5296/emsd.v5i2.10187

\begin{abstract}
Arsenic removal is hindered by its valence state. Addition of lime into wastewater containing arsenic gives benefits through the formation of low-soluble calcium arsenate, but the mechanism involved in the reduction of arsenic dissolution is not well known yet. Hence, in the present work different $\mathrm{Ca} / \mathrm{As}$ ratios from 0 to $70 \% \mathrm{w} / \mathrm{w}$ were tested with the aim of finding the best conditions for removal of As from water (neutral tests) or solution (acid tests) containing sulphate ions. These solutions simulated aqueous streams coming from a wet scrubber for treatment of flue gas. Moreover, $5 \mathrm{~g} \mathrm{~L}^{-1}$ of iron chloride were tested as additive in the acid tests.

In the optimum operating conditions, nearly $99 \%$ precipitation yield was obtained for both $\mathrm{As}(\mathrm{III})$ and $\mathrm{As}(\mathrm{V})$ in less than $1 \mathrm{~h}$; the optimum process conditions were $10 \mathrm{~g} \mathrm{~L}^{-1}$ of $\mathrm{CaO}$ without $\mathrm{FeCl}_{3}$ for $\mathrm{As}(\mathrm{III})$ and $9 \mathrm{~g} \mathrm{~L}^{-1}$ of $\mathrm{CaO}$ and $5 \mathrm{~g}^{-1} \mathrm{FeCl}_{3}$ for $\mathrm{As}(\mathrm{V})$ in acid solutions. As regards neutral solutions, $1 \mathrm{~g} \mathrm{~L}^{-1}$ of $\mathrm{CaO}$ is enough to precipitate around $99 \%$ of $\mathrm{As}(\mathrm{III})$ whereas the same result for $\mathrm{As}(\mathrm{V})$ is achieved by a higher $\mathrm{CaO}$ concentration $\left(40 \mathrm{~g} \mathrm{~L}^{-1}\right)$. Iron chloride had a negative effect on As(III) precipitation.
\end{abstract}

Keywords: Arsenic; Flue gas; Scrubbing; Lime; Precipitation

\section{Introduction}

Arsenic contamination causes severe health problems around the world. Arsenic has found widespread use in agriculture and industry. Most of these activities have been broken off, but 


\section{Al Macrothink ER 2016, Vol. 5, No. 2}

residues and the generation of arsenic wastes from smelting of various ores produce environmental pollution. Arsenic can be found in waste streams from a variety of industrial processes. For example, arsenic wastes are generated from petroleum refining, glass melting, and the smelting of ores that are mined for their lead, copper, zinc, gold and silver contents. Arsenic is also released into the environment by the dispersion of arsenic-containing fertilizers, pesticides and wood preservatives (Bothe and Brown, 1999). Some methods for removal of arsenic from various industrial effluents have been studied and proposed. Arsenic can not be destroyed but only converted into different forms or transformed into insoluble or stable compounds in combination with other elements, such as iron. Arsenic wastes may contain many impurities such as lead, iron and selenium. These elements can often be expensive to remove and arsenic is stockpiled as waste. However, arsenic with a purity greater than 95\% may economically be recovered for manufacture of arsenical wood preservative, chromates copper arsenate (CCA) and ammoniacal copper-zinc arsenate (ACZA). The largest end use for arsenic trioxide is in production of wood preservatives (Reese, 2016). High purity arsenic metal $(\geq 99.99 \%)$ is used in manufacture of crystalline gallium arsenide, a semi-conductive material used in optoelectronic circuitry, high speed computers and other electronic devices.

Arsenic can be removed from contaminated water by both physico-chemical and biological methods. These are classified below:

(I) physico-chemical techniques:

(a) adsorption;

(b) ion exchange;

(c) precipitation-coagulation;

(d) membrane filtration;

(e) permeable reactive methods.

(II) Biological techniques:

(a) phytoremediation;

(b) biological treatment with living microbes or bio-filtration.

Table 1 shows advantages and disadvantages of the physico-chemical methods. 


\section{Macrothink}

Table 1. Physico-chemical methods: advantages and disadvantages

\begin{tabular}{|l|l|l|}
\hline Method & Advantages & Disadvantages \\
\hline $\begin{array}{l}\text { Co-Precipitation } \\
\text { (alum/iron coagulation, lime softening) }\end{array}$ & $\begin{array}{l}\text { - Relatively low cost, } \\
\text { simple chemicals. } \\
\text { - No monitoring of } \\
\text { breakthrough required. }\end{array}$ & $\begin{array}{l}\text { - Toxic sludge generation and } \\
\text { disposal on daily basis. } \\
\text { - Chemical consumables. } \\
\text { - Pre-oxidation and pH } \\
\text { adjustment often required. }\end{array}$ \\
$\begin{array}{l}\text { Sorption Techniques } \\
\text { (activated alumina, iron coated sand, iron } \\
\text { oxides, ion exchange resins) }\end{array}$ & $\begin{array}{l}\text { - No daily sludge } \\
\text { - Feneration or disposal. } \\
\text { consumables. }\end{array}$ & $\begin{array}{l}\text { - Higher cost than precipitation. } \\
\text { - Monitoring of break through } \\
\text { required. }\end{array}$ \\
\hline $\begin{array}{l}\text { - Periodic regeneration required. } \\
\text { - pH adjustment often required. }\end{array}$ \\
$\begin{array}{l}\text { Membrane Techniques } \\
\text { reverse osmosis, electrodialysis) }\end{array}$
\end{tabular}

At the moment mining industry prefers arsenic disposal procedures that involve formation of an insoluble amorphous or poorly crystalline ferric arsenate compound; this amorphous salt is similar to arsenical ferrihydrite. Despite concerns about its long-term thermodynamic stability, arsenical ferrihydrite seems to be stable for many years in a proper environment, which includes a slightly acidic $\mathrm{pH}$ and oxidizing conditions. High Fe/As ratio and presence of heavy metals seem to increase the stability of arsenical ferrihydrite. High temperature operations lead to the formation of scorodite $\left(\mathrm{FeAsO}_{4} \cdot 2 \mathrm{H}_{2} \mathrm{O}\right)$ and/or a series of ferric arseno-sulphate compounds, depending on concentration of sulphate ions.

Scorodite has several advantages over arsenical ferrihydrite as disposal compound, including a lower iron demand, higher density and a greater thermodynamic stability. New procedures were developed to generate scorodite at ambient pressure, which would offer a significant reduction in capital cost because of elimination of the required autoclaves.

Harper and Kingham (1992) used chemical precipitation by means of alum, sodium sulphide or ferric chloride as coagulant with hydrate lime for $\mathrm{pH}$ adjustment. To improve As removal up to $98 \%$, they concluded that a multiple dosage is necessary. Bhattacharyya and his group studied metal precipitation by sodium sulphide (Bhattacharyya et al., 1980). Namasivayam and Senthil Kumar (1998) studied the use of $\mathrm{Fe}(\mathrm{III}) / \mathrm{Cr}$ (III) hydroxide waste coming from an electrolytic process of fertilizer industry. Alum and ferric sulphate were also tested for arsenic removal (Gulledge et al., 1973). Tokunaga et al. (1999) found that the complete removal of As(III) is not possible, whereas the best removal was achieved with As(V): different salts were investigated ( $\mathrm{La}(\mathrm{III}), \mathrm{Al}(\mathrm{III}), \mathrm{Ca}(\mathrm{II}), \mathrm{Fe}(\mathrm{III})$ ) and $\mathrm{Fe}(\mathrm{III})$ gave the best results for both 
As(III) and As(V). Hering et al. (1996) concluded that alum can not remove As(III), whereas As(III) removal by ferric chloride is influenced by the composition of source water; moreover, the presence of sulphates and organic matter negatively affected As(III) precipitation. Arsenic-containing tailings or residues create several environmental problems when stockpiled improperly; as an example, in Snow Lake, Manitoba (Canada) cyanide tailings from refractory arsenopyrite ore concentrate processing are still releasing arsenic, because of the action of water and air that has oxidized many of the original compounds and produced two different iron sulfo-arsenates, usually more stable but not in the particular reducing conditions of the pile. Groundwater collected from monitoring wells contains more than 20 $\mathrm{mg} \mathrm{L}^{-1}$ total As with predominance of As(III) (Salzsauler et al., 2005).

Arsenic mobilization and speciation was also studied in the aquifers in the surroundings of a an inactive Mexican smelting plant. Calcium arsenates caused high levels of pollution, as the As in groundwater table concentration was $158 \mathrm{mg} \mathrm{L}^{-1}$ and the total As release was estimated to be around 7.5 tons per year. Free calcium ions in soil are able to control arsenic mobility in the aquifer through the diagenetic precipitation of calcium arsenates $\mathrm{Ca}_{5} \mathrm{H}_{2}\left(\mathrm{AsO}_{4}\right) 4 \cdot \mathrm{nH}_{2} \mathrm{O}$, preventing further mobilization of As (Martínez-Villegas et al., 2013).

An in situ experimental study for chemical fixation of arsenic in arsenic-contaminated subsurface soils was carried out by Yang et al. (2007). Ferrous sulfate, potassium permanganate and calcium carbonate were used alone and in combination to limit the release of arsenic. EPA method 1312 and TCLP were used for evaluation of As mobility. All treatments were found to be effective for both soils, reducing the arsenic leachability. Nevertheless, treatment with ferrous sulfate gave the best results in terms of As concentration in the leachate. Arsenic organic and inorganic chemistry in soils was well described by Sadiq (1997). Guenegou et al. (1997) studied arsenic elimination by precipitation of calcium arsenite and arsenate, as well as co-precipitation in presence of iron(III) from aqueous solutions obtained by hydrolysis of Lewisites, with 0.1 and $1 \mathrm{~mol} \mathrm{~L}^{-1}$ of arsenic and chloride ions, respectively. The calcium arsenite precipitation entails an arsenic precipitation yield of $80 \%$ at $\mathrm{pH} 11$ and with addition of calcium ions in a molar ratio $\mathrm{Ca}^{2+} / \mathrm{As}^{+}$of 15 .

Palfy et al. (1999) demonstrated that it is possible to reduce the arsenic solubility of untreated waste sludges from $6430 \mathrm{mg} \mathrm{L}^{-1}$ to $0.823 \mathrm{mg} \mathrm{L}^{-1}$ by arsenic stabilization. In particular, arsenic was precipitated and immobilized by using ferric sulphate, calcium oxide and hydrogen peroxide to oxidize As(III) into As(V). Ca/As molar ratios greater than 8 did not increase As reduction in solution; Fe/As molar ratios 4 and 6 were also tested for a reaction time of $24 \mathrm{~h}$. Arsenic was thus immobilized by the addition of Portland cement to avoid long term stability problems of the precipitated salts. The same immobilization technique was used by Kundu and Gupta (2008). Addition of lime and cement showed an effective containment of As(III) within the matrix. The solidification and stabilization technique with lime and Portland cement was applied successfully to the immobilization of arsenic wastewater residuals by Camacho et al. (2009). In particular, it was also demonstrated the stabilization effect of calcium. Anyway, precipitated material obtained by the sole addition of lime is not stable over time, since the buffering effect of lime decreased by dissolution and carbonation when exposed to atmospheric $\mathrm{CO}_{2}$. Arsenate desorption was induced by using both de-ionized 
water and phosphate solution and demonstrate the good stability of the precipitated material obtained by cement. Stabilization of arsenic by calcium precipitation was also investigated by Moon et al. (2004). With $\mathrm{As}(\mathrm{V})$ in solution, precipitation of $\mathrm{Ca}_{4}(\mathrm{OH})_{2}\left(\mathrm{AsO}_{4}\right)_{2} \cdot 4 \mathrm{H}_{2} \mathrm{O}$ occurred with $\mathrm{Ca}$ /As molar ratios greater than 1 . Addition of kaolinite was also studied. In the latter case formation of $\mathrm{NaCaAsO}_{4} \cdot 7.5 \mathrm{H}_{2} \mathrm{O}$ was detected in the precipitate when As was in the pentavalent form. When As(III) was precipitated, three main phases were detected in the precipitate: portlandite, calcium arsenite and calcite. Results showed that the effectiveness of both $\mathrm{As}(\mathrm{III})$ and $\mathrm{As}(\mathrm{V})$ immobilization increased with higher $\mathrm{Ca} / \mathrm{As}$ molar ratios. Removal and stabilization of arsenic from industrial process solutions, sludges and solid residues is a technical problem of great importance. For instance, Yuhu et al. (2011) described a leaching process to remove selectively As from Waelz zinc oxide. The pregnant solution, containing $10.37 \mathrm{~g} \mathrm{As} \mathrm{L}^{-1}$ was treated by hydrogen peroxide followed by lime precipitation with a lime/As molar ratio equal to $3: 1$, at $90^{\circ} \mathrm{C}$ for $2 \mathrm{~h}$, which removed $99.86 \%$ of arsenic, with a residual concentration of $2 \mathrm{mg} \mathrm{L}^{-1}$ in the solution. The precipitate of cristalline calcium arsenate $\mathrm{Ca}_{5}\left(\mathrm{AsO}_{4}\right)_{3} \mathrm{OH}$ was solidified with cement and thus landfilled. Arsenic stabilization also involves copper smelter industry. Viñals et al. (2010) investigated precipitation of arsenical natroalunite, that is suitable for long-term storage, from a calcium arsenate waste coming from a copper pyrometallurgical plant. Calcium arsenate waste was leached with $\mathrm{H}_{2} \mathrm{SO}_{4}$ and ozonized at $25^{\circ} \mathrm{C}$ to convert As(III) to As(V). Hydrothermal synthesis of arsenical natroalunite was carried out in a pressurised reactor at $200^{\circ} \mathrm{C}$ for $2 \mathrm{~h}$. Leaching tests at $\mathrm{pH} 1$ demonstrated a good stability of the salt obtained: the best result showed an arsenic concentration lower than $1 \mathrm{mg} \mathrm{L}^{-1}$ in the leachate.

Sturgill et al. (2000) developed a process for simultaneous recovery of arsenic and gallium from GaAs polishing waste. That process involved the removal of the majority of arsenic as a mixed precipitate of calcium arsenate. In a first step at ambient temperatures and $\mathrm{pH}$ greater than 11 by using $\mathrm{NaOH}$, arsenic precipitated and gallium remained in solution. Hence, gallium hydroxide was precipitated in the second process stage through $\mathrm{pH}$ adjustment to 6-8 with sulphuric acid.

The influence of calcite $\left(\mathrm{CaCO}_{3}\right)$ in sequestration of arsenic is also known (Winkel et al., 2013). Furthermore, the role of calcium ions is also described in the analysis of arsenic and selenium leaching of bituminous coal ash and following precipitation (Wang et al., 2009). In the present work removal of $\mathrm{As}(\mathrm{III})$ and $\mathrm{As}(\mathrm{V})$ from acid and neutral solutions was investigated. These solutions simulate typical arsenic concentrations resulting from a wet scrubber of flue gas coming from roasting processes of auriferous ores; it is well know that such ores are mainly composed by sulphides and arsenic is often present as well. This work was carried out in the ambit of a project for recovery of gold from auriferous arsenopyrite deposit in Lazio region, Italy: after grinding, such ore undergoes thermal oxidation at temperatures around $700^{\circ} \mathrm{C}$, in order to remove sulphur, and the sublimated arsenic is captured by a wet scrubber together with $\mathrm{SO}_{2}$. Hence, arsenic has to be removed and deactivated for safe disposal. Flue gas emissions from roasting processes have to be treated before releasing into the atmosphere, according to the best and effective technologies. The Italian decree D.P.R. 24 May 1988, n.203 reports air quality regulations and it disciplines all 
emissions (solid, liquid and gaseous) produced by industrial plants. The D.Lgs. 152/2007 lists the limit of emission, whereas the D.Lgs. 152/2006 reports criteria for sampling and analysis.

The aim of this experimental work was to study how $\mathrm{CaO}, \mathrm{FeCl}_{3}$ and sulphate ions concentrations affect the precipitation of arsenic. In fact, it is of primary importance to obtain arsenic compounds chemically stable that can be disposed of in a safe way, avoiding release into soil, groundwater table or water bodies. When $\mathrm{Fe}^{3+}$ ions are present in solution at high $\mathrm{pH}$, arsenic precipitation by calcium is improved by the adsorption effect of $\mathrm{Fe}(\mathrm{OH})_{3}$, which acts as coagulant with a large surface area.

\section{Experimental}

Precipitation tests were performed by four synthetic solutions containing As(III) or As(V). Two solutions were prepared by addition of $\mathrm{As}_{2} \mathrm{O}_{3}$ (chemical grade 99.95\%, Sigma-Aldrich) or $\mathrm{As}_{2} \mathrm{O}_{5}$ (chemical grade 99\%, Sigma-Aldrich) in $2 \mathrm{~L}$ of $0.1 \mathrm{M} \mathrm{H}_{2} \mathrm{SO}_{4}$ solution (acid tests). The concentrations were those obtained by dissolving a weighted amount of both $\mathrm{As}_{2} \mathrm{O}_{3}$ and $\mathrm{As}_{2} \mathrm{O}_{5}$ in the two different solutions, i.e. neutral and acid; these concentrations are representative of the typical ones that can be found in wet scrubber wastewater that treats flue gas from thermal oxidation of sulphide/arsenic-containing ores. Hence, before performing the precipitation tests, the four solutions were filtered by a vacuum pump (Millipore) and analyzed by atomic adsorption spectrometry (AAS) to determine the effective concentration of $\mathrm{As}(\mathrm{III})$ or $\mathrm{As}(\mathrm{V})$; in fact, in such conditions $\mathrm{As}(\mathrm{III})$ has a low solubility and the total amount was not dissolved. The real concentrations measured by AAS were used to evaluate the precipitation yields.

The precipitation tests were carried out in $250 \mathrm{~mL}$ screw flasks at constant temperature in a water bath mechanically stirred (Dubnoff, ISCO) at $200 \mathrm{rpm}$. There is a significant effect on kinetics of scorodite precipitation by varying the temperature from $80^{\circ} \mathrm{C}$ up to the boiling point of the solution (Singhania et al., 2005), so that the temperature was set at $80^{\circ} \mathrm{C}$.

The same experimental procedure was carried out (see Table 3 for acid tests and Table 4 for neutral tests) for all solutions: a series of flasks was filled with $100 \mathrm{~mL}$ of solution containing $\mathrm{As}(\mathrm{III})$ or $\mathrm{As}(\mathrm{V})$ and a different amount of $\mathrm{CaO}$ (reagent grade, Fluka) was added to each flask.

Several samples were taken at 5, 15, 45, 90 and 120 minutes, centrifuged at $5000 \mathrm{rpm}$ and analysed for arsenic determination by AAS (Varian, spectrophotometer Spectra AA-200). $\mathrm{pH}$ was measured by a digital $\mathrm{pH}$-meter (Mettler Toledo MP220). Acid tests were replicated with the addition of $5 \mathrm{~g} \mathrm{~L}^{-1}$ of $\mathrm{FeCl}_{3} \cdot 6 \mathrm{H}_{2} \mathrm{O}$ (97\% grade, Fluka) as coagulant (see Table 5). The X-ray diffraction analysis (XRD) was carried out by a Philips PW 1830 diffractometer in order to establish the crystalline phases present in some of the precipitated samples, in order to confirm theoretical precipitation data.

\section{Results and Discussion}

A brief introduction to the chemistry of the aqueous system is shown as follows. A comparison between the solubility constant $(\mathrm{K})$ and the activity product $(\mathrm{Q})$ permits to 
understand whether the acid or neutral solution at $80^{\circ} \mathrm{C}$ are undersaturated $(\mathrm{Q}<\mathrm{K})$, at equilibrium with $\mathrm{Q}=\mathrm{K}$ or oversaturated $(\mathrm{Q}>\mathrm{K})$ in presence of a particular mineral.

Table 2 shows the mineral saturation index (SI) at different pHs:

$$
\mathrm{SI}=\log (\mathrm{Q})-\log (\mathrm{K})
$$

These values were calculated by Phreeqc Interactive 2.14.3 software, in acid condition $\left(\mathrm{H}_{2} \mathrm{SO}_{4} 0.1 \mathrm{M}\right)$, arsenic $1 \mathrm{~g} \mathrm{~L}^{-1}, \mathrm{CaO} 1 \mathrm{~g} \mathrm{~L}^{-1}$ and $\mathrm{FeCl}_{3} 5 \mathrm{~g} \mathrm{~L}^{-1}$ as software input data.

Table 2. Saturation index of minerals in acid solution $\left(\mathrm{H}_{2} \mathrm{SO}_{4} 0.1 \mathrm{M}\right)$ with $\mathrm{CaO}\left(12 \mathrm{~g} \mathrm{~L}^{-1}\right)$ and $\mathrm{FeCl}_{3}\left(5 \mathrm{~g} \mathrm{~L}^{-1}\right)$ at different $\mathrm{pHs}$

\begin{tabular}{|l|r|r|r|r|l|r|r|r|r|}
\hline \multicolumn{5}{|c|}{$\mathrm{As}(\mathrm{III})$} & \multicolumn{7}{c|}{$\mathrm{As}(\mathrm{V})$} \\
\hline & $\mathrm{pH} 1$ & $\mathrm{pH} 4$ & $\mathrm{pH} 8$ & $\mathrm{pH} 12$ & & $\mathrm{pH} 1$ & $\mathrm{pH} 4$ & $\mathrm{pH} 8$ & $\mathrm{pH} 12$ \\
\hline Arsenolite & -3.13 & -3.09 & -3.52 & -10.7 & $\mathrm{As}_{2} \mathrm{O}_{5}(\mathrm{cr})$ & -11.03 & -14.45 & -25.23 & -44.24 \\
\hline As native & -7.45 & -16.43 & -28.64 & -44.23 & $\mathrm{Ca}_{3}\left(\mathrm{AsO}_{4}\right)_{2}$ & -24.46 & -10.06 & 3.15 & 8.03 \\
\hline Claudetite & -3.13 & -3.09 & -3.52 & -10.7 & $\mathrm{Fe}(\mathrm{OH})_{2.7} \mathrm{Cl}_{0.3}$ & 1.73 & 7.39 & 8.25 & 3.38 \\
\hline $\mathrm{Fe}(\mathrm{OH})_{2.7} \mathrm{Cl}_{0.3}$ & 1.73 & 7.39 & 8.25 & 3.37 & $\mathrm{Fe}(\mathrm{OH})_{3}(\mathrm{a})$ & -5.52 & 1.03 & 3.09 & -0.58 \\
\hline $\mathrm{Fe}(\mathrm{OH})_{3}(\mathrm{a})$ & -5.52 & 1.03 & 3.09 & -0.58 & Goethite & 2.03 & 8.58 & 10.63 & 6.97 \\
\hline Goethite & 2.03 & 8.58 & 10.63 & 6.97 & Hematite & 6.28 & 19.39 & 23.49 & 16.17 \\
\hline Hematite & 6.28 & 19.39 & 23.49 & 16.16 & Jarosite & -0.36 & 9.12 & -0.71 & -27.7 \\
\hline Jarosite & -0.36 & 9.12 & -0.71 & -27.7 & Maghemite & -7.63 & 5.47 & 9.58 & 2.26 \\
\hline Maghemite & -7.63 & 5.47 & 9.57 & 2.25 & Scorodite & -2.93 & 1.91 & -1.43 & -14.6 \\
\hline
\end{tabular}

It is possible to notice that all As(III) minerals show a negative SI: this means that the solution is in undersaturated conditions with respect to those minerals. As regards $A s(V)$, $\mathrm{Ca}_{3}\left(\mathrm{AsO}_{4}\right)_{2}$ shows a positive $\mathrm{SI}$ at $\mathrm{pH}$, thus oversaturated conditions occurred at alkaline pHs. Scorodite has a positive SI at $\mathrm{pH} \mathrm{4,} \mathrm{whereas} \mathrm{at} \mathrm{different} \mathrm{pHs}$ the SI is negative: this means that this compound can precipitate and solubilized again when $\mathrm{pH}$ increased. In our system other possible minerals containing $\mathrm{As}(\mathrm{V})$ and $\mathrm{As}(\mathrm{III})$ such as rauenthalite $\left(\mathrm{Ca}_{3}\left(\mathrm{AsO}_{4}\right)_{2} \cdot 10 \mathrm{H}_{2} \mathrm{O}\right)$ and calcium arsenite $\left(\mathrm{CaHAsO}_{3}\right)$ are not present, as for instance in other more complex aqueous systems (Cornelis et al., 2008).

\subsection{Acid Tests}

Precipitation tests of arsenic from $0.1 \mathrm{M}$ sulphuric acid solutions were performed by $\mathrm{CaO}$ with or without addition of $\mathrm{FeCl}_{3}$ as coagulant. The aim of these tests was to check the effect of sulphate ions on As precipitation, as they simulated a process for treatment of wet scrubber's spent solutions used to remove arsenic from flue gas. As a matter of fact, flue gas coming from roasting of auriferous ore usually contains great amounts of arsenic and $\mathrm{SO}_{2}$.

Table 3 shows the initial concentration of As(III) and As(V) measured by AAS and the $\mathrm{CaO} / \mathrm{As}$ ratio. 


\section{Macrothink}

Table 3. Experimental conditions of acid tests carried out without addition of $\mathrm{FeCl}_{3}$; temperature $80^{\circ} \mathrm{C}$

\begin{tabular}{|c|c|c|c|c|c|}
\hline Treatment & As ion & As, $\mathrm{mg} \mathrm{L}^{-1}$ (measured) & ${\mathrm{CaO}, \mathrm{g} \mathrm{L}^{-1}}^{\mathrm{g} \mathrm{CaO} / \mathrm{g} \text { As }}$ & $\mathrm{pH}(2 \mathrm{~h})$ \\
\hline 1 & As (III) & 432 & 0 & 0.0 & 1.52 \\
\hline 2 & As (III) & 432 & 1 & 2.3 & 1.56 \\
\hline 3 & As (III) & 432 & 5 & 11.6 & 1.83 \\
\hline 4 & As (III) & 432 & 7 & 16.2 & 10.61 \\
\hline 5 & As (III) & 432 & 10 & 23.1 & 11.61 \\
\hline 6 & As (III) & 432 & 12 & 27.8 & 11.63 \\
\hline 7 & As (V) & 1046 & 0 & 0 & 1.52 \\
\hline 8 & As (V) & 1046 & 1 & 1 & 1.56 \\
\hline 9 & As (V) & 1046 & 5 & 5 & 1.83 \\
\hline 10 & As (V) & 1046 & 7 & 7 & 10.61 \\
\hline 11 & As (V) & 1046 & 10 & 10 & 11.61 \\
\hline 12 & As (V) & 1046 & 12 & 12 & 11.63 \\
\hline
\end{tabular}

As it can be inferred from Table 3, As(III) is less soluble than As(V) even in acid medium. pH of reference samples $\left(0 \mathrm{~g} \mathrm{~L}^{-1}\right.$ of $\mathrm{CaO}$, treatments 1 and 7) was about 1.5. pHs were almost constant during the tests (data not shown here).

$\mathrm{pH}$ of treatments 2 and 3 did not change with respect to the reference sample, whereas in the remaining treatments the $\mathrm{pH}$ achieved values around 11 . Treatments 4,11 and 12 showed a slow kinetics and the equilibrium $\mathrm{pH}$ was reached after 90, 45 and 15 minutes, respectively. In the other treatments the equilibrium $\mathrm{pH}$ was already reached after 5 minutes. Figures 1 and 2 show the concentration trend of $\mathrm{As}(\mathrm{III})$ and $\mathrm{As}(\mathrm{V})$, respectively. The reference sample containing $0 \mathrm{~g} \mathrm{~L}^{-1}$ of $\mathrm{CaO}$ shows that the solubility of As(III) decreases with time (Fig.1), instead, it is constant for As(V) (Fig.2). These results indicate that the greater the amount of $\mathrm{CaO}$, the higher the process kinetics. Furthermore, As(III) showed better precipitation kinetics than $\mathrm{As}(\mathrm{V})$.

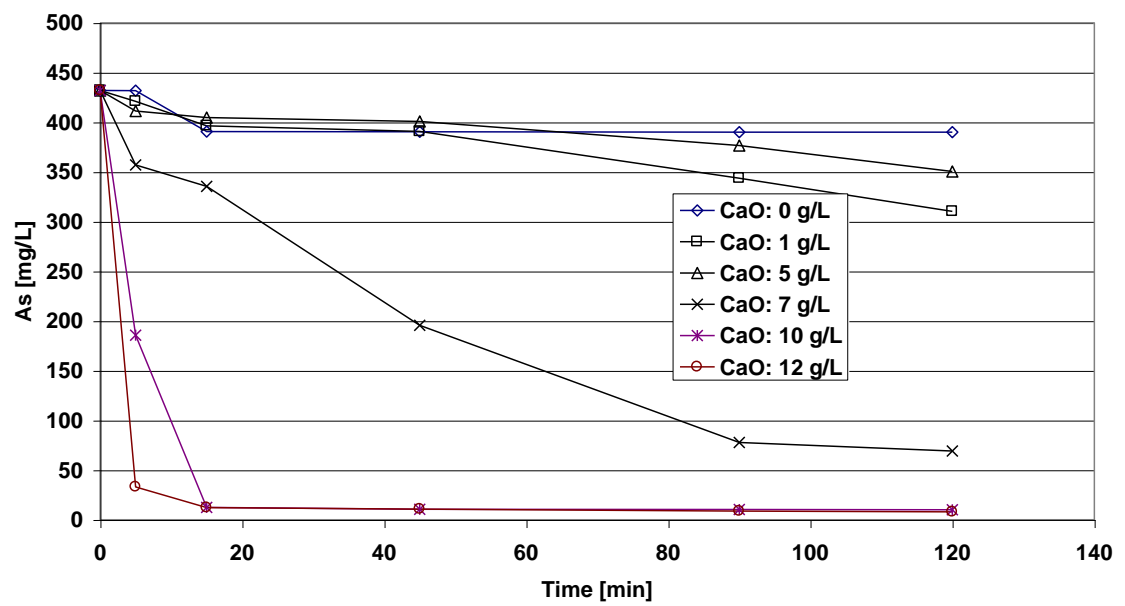

Figure 1. As(III) concentration vs time (treatments $1 \div 6$ in Table 3: reference value $0 \mathrm{~g}$ $\mathrm{L}^{-1}$ of $\left.\mathrm{CaO}\right)$. 


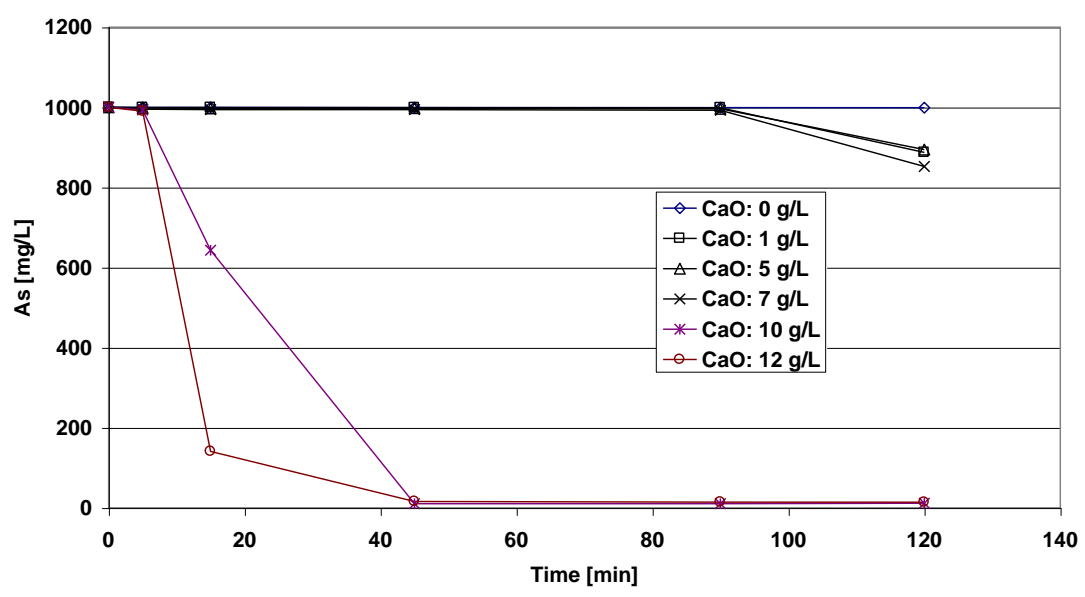

Figure 2. As $(\mathrm{V})$ concentration vs time (treatments $7 \div 12$ in Table 3: reference value $0 \mathrm{~g}$ $\mathrm{L}^{-1}$ of $\mathrm{CaO}$, dotted line).

Figure 3 reports arsenic precipitation yields at two different times for each treatment; it is possible to notice that after 5 minutes $\mathrm{As}(\mathrm{V})$ is not removed whereas As(III) removal yield is around $92 \%$ with $12 \mathrm{~g} \mathrm{~L}^{-1}$ of $\mathrm{CaO}$. Increasing process time the precipitation yields increase until $98 \%$ for both $\mathrm{As}(\mathrm{III})$ and $\mathrm{As}(\mathrm{V})$ when the highest $\mathrm{CaO}$ concentration is present, i.e. $12 \mathrm{~g}$ $\mathrm{L}^{-1}$.

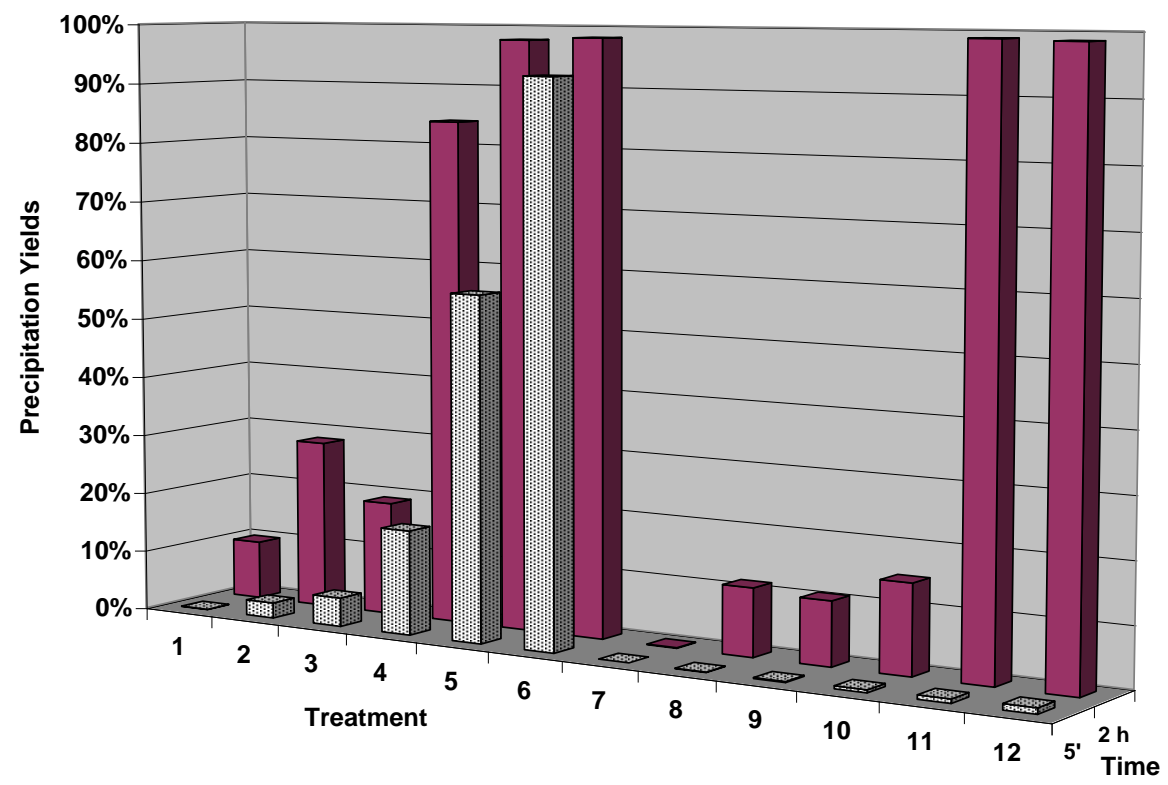

Figure 3. Arsenic precipitation yields at two different process time, treatments without $\mathrm{FeCl}_{3}$ (treatments $1 \div 12$ in Table 3 ).

Those treatments described before were repeated by addition of $5 \mathrm{~g} \mathrm{~L}^{-1}$ of ferric chloride. Table 4 reports the experimental plan. 


\section{Macrothink}

Table 4. Experimental conditions of acid tests carried out with $\mathrm{FeCl}_{3}\left(5 \mathrm{~g} \mathrm{~L}^{-1}\right)$; temperature $80^{\circ} \mathrm{C}$

\begin{tabular}{|c|c|c|c|c|c|}
\hline Treatment & As ion & As, $\mathrm{mg} \mathrm{L}^{-1}$ (measured) & ${\mathrm{CaO}, \mathrm{g} \mathrm{L}^{-1}}^{\mathrm{g} \mathrm{CaO} / \mathrm{g} \mathrm{As}}$ & $\mathrm{pH}(2 \mathrm{~h})$ \\
\hline 13 & As (III) & 180 & 0 & 0.0 & 1.19 \\
\hline 14 & As (III) & 180 & 5 & 27.8 & 1.48 \\
\hline 15 & As (III) & 180 & 7 & 38.9 & 1.67 \\
\hline 16 & As (III) & 180 & 8 & 44.4 & 1.67 \\
\hline 17 & As (III) & 180 & 9 & 50.0 & 1.68 \\
\hline 18 & As (III) & 180 & 12 & 66.7 & 1.83 \\
\hline 19 & As (V) & 1073 & 0 & 0 & 1.16 \\
\hline 20 & As (V) & 1073 & 5 & 5 & 1.71 \\
\hline 21 & As (V) & 1073 & 7 & 7 & 1.67 \\
\hline 22 & As (V) & 1073 & 8 & 8 & 1.77 \\
\hline 23 & As (V) & 1073 & 9 & 9 & 1.80 \\
\hline 24 & As (V) & 1073 & 12 & 12 & 1.90 \\
\hline
\end{tabular}

The addition of ferric chloride does not have any effect on $\mathrm{As}(\mathrm{V})$ concentration. The initial concentration of $\mathrm{As}$ (III) is lower than that of $\mathrm{As}(\mathrm{III})$ measured in the solution without $\mathrm{FeCl}_{3}$, i.e. $180 \mathrm{mg} \mathrm{L}^{-1}$ against $432 \mathrm{mg} \mathrm{L}^{-1}$. This means that in this range of $\mathrm{pH}$ ferric chloride reduces the solubility of As(III) whereas does not influence the solubility of As(V).

In these treatments (data not reported) the equilibrium $\mathrm{pH}$ value is reached after 5 minutes and remains constant throughout the tests, but the $\mathrm{pH}$ increment is not so high as in the other treatments, where the final $\mathrm{pH}$ is close to 11 . The $\mathrm{pH}$ of the reference sample is around 1.2, whereas the $\mathrm{pH}$ of treatments 13-24 ranges from 1.5 to 2 .

Figures 4 and 5 show the concentration trends of arsenic. In the reference test, As(III) concentration decreases with time, as in the previous tests. It can be inferred from Figures 4 and 5 that $\mathrm{As}(\mathrm{V})$ precipitation kinetics is faster than that of $\mathrm{As}(\mathrm{III})$.

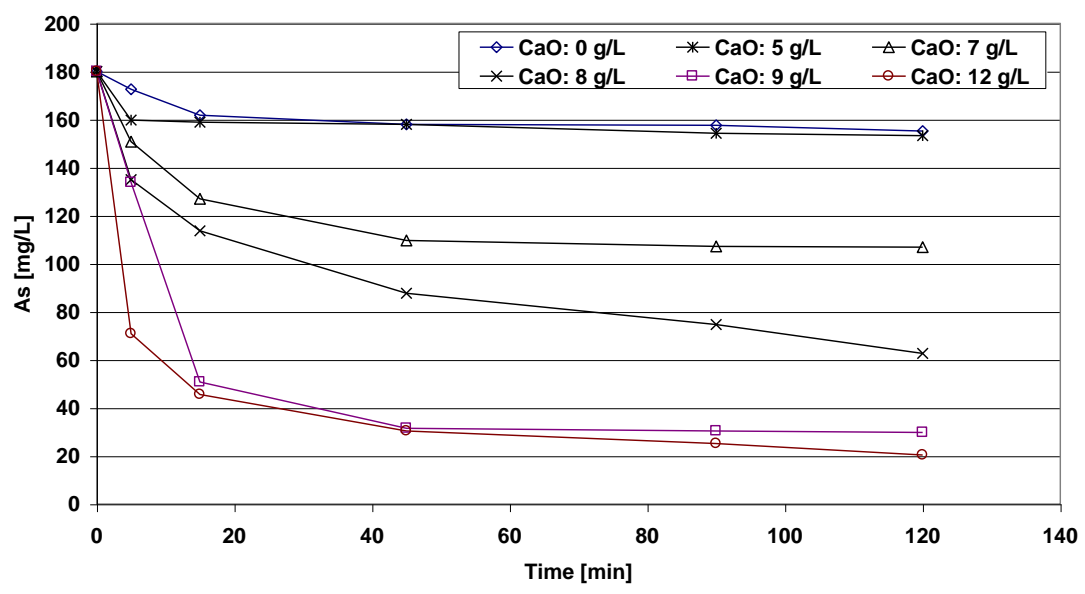

Figure 4. As(III) concentration vs time (treatments $13 \div 18$ in Table 4: reference value $0 \mathrm{~g}$ $\mathrm{L}^{-1}$ of $\mathrm{CaO}$ ). 


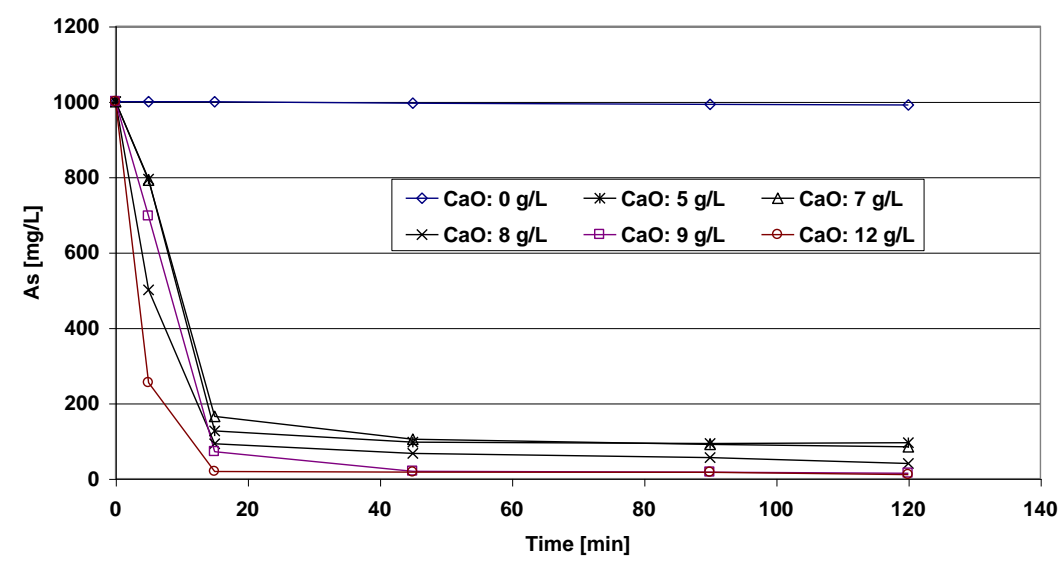

Figure 5. As(V) concentration vs time (treatments 19-24 in Table 4: reference value $0 \mathrm{~g}$ $\mathrm{L}^{-1}$ of $\mathrm{CaO}$, dotted line).

Figure 6 shows arsenic precipitation yields at two different process times for every treatment. It is possible to note that most of $\mathrm{As}(\mathrm{V})$ is already removed after 5 minutes (75\% with $12 \mathrm{~g}$ $\mathrm{L}^{-1}$ of $\mathrm{CaO}$ ) because of ferric chloride; $\mathrm{As}(\mathrm{III})$ yield is about $60 \%$ by using the same amount of $\mathrm{CaO}$, so that the removal is lower than that obtained in the test without coagulant. When the process time increases the precipitation yields increase up to $88 \%$ and $99 \%$ for As(III) and As $(\mathrm{V})$, respectively.

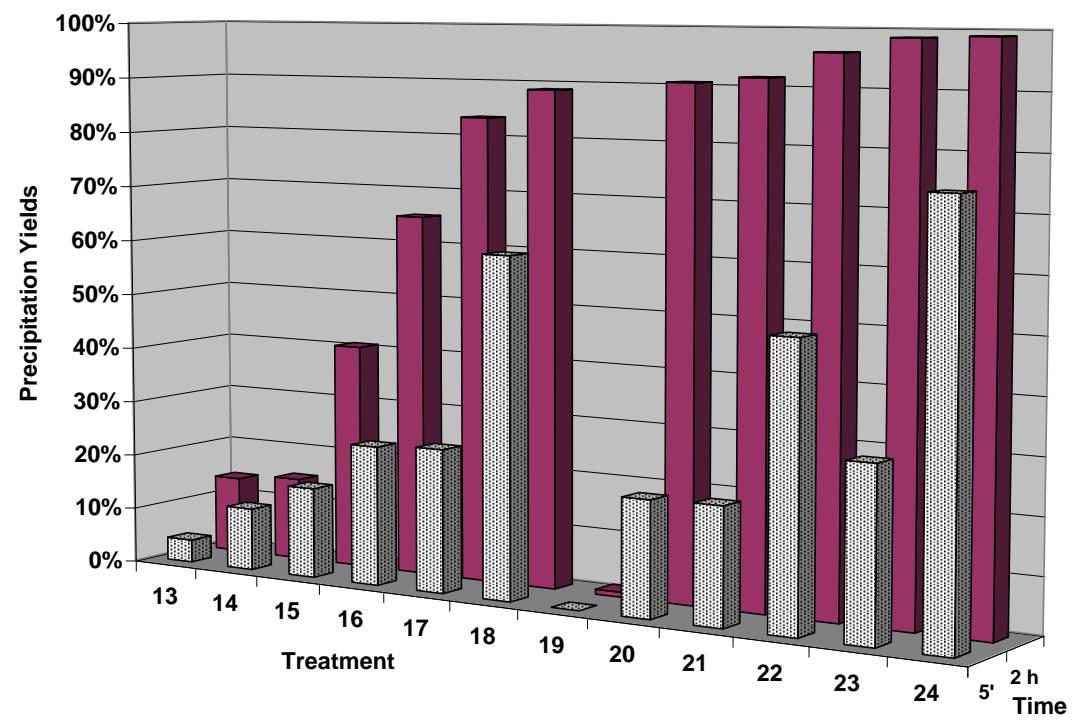

Figure 6. Arsenic precipitation yields at two different process time, treatments with $\mathrm{FeCl}_{3}\left(5 \mathrm{~g} \mathrm{~L}^{-1}\right.$, treatments $13-24$ in Table 4$)$.

Figure 7 shows the precipitation yields for those treatments carried out with and without ferric chloride, keeping constant the amount of $\mathrm{CaO}$ (see tables 3 and 4 for experimental conditions). The precipitation yield of As(III) decreases when the coagulant is added and this is true for every $\mathrm{CaO}$ concentration. In treatment 6 , As concentration is around $8 \mathrm{mg} \mathrm{L}^{-1}$ and the precipitation yield close to $98 \%$ after $2 \mathrm{~h}$, whereas in treatment 18 the concentration of As is more than double, i.e. nearly $20 \mathrm{mg} \mathrm{L}^{-1}$. 


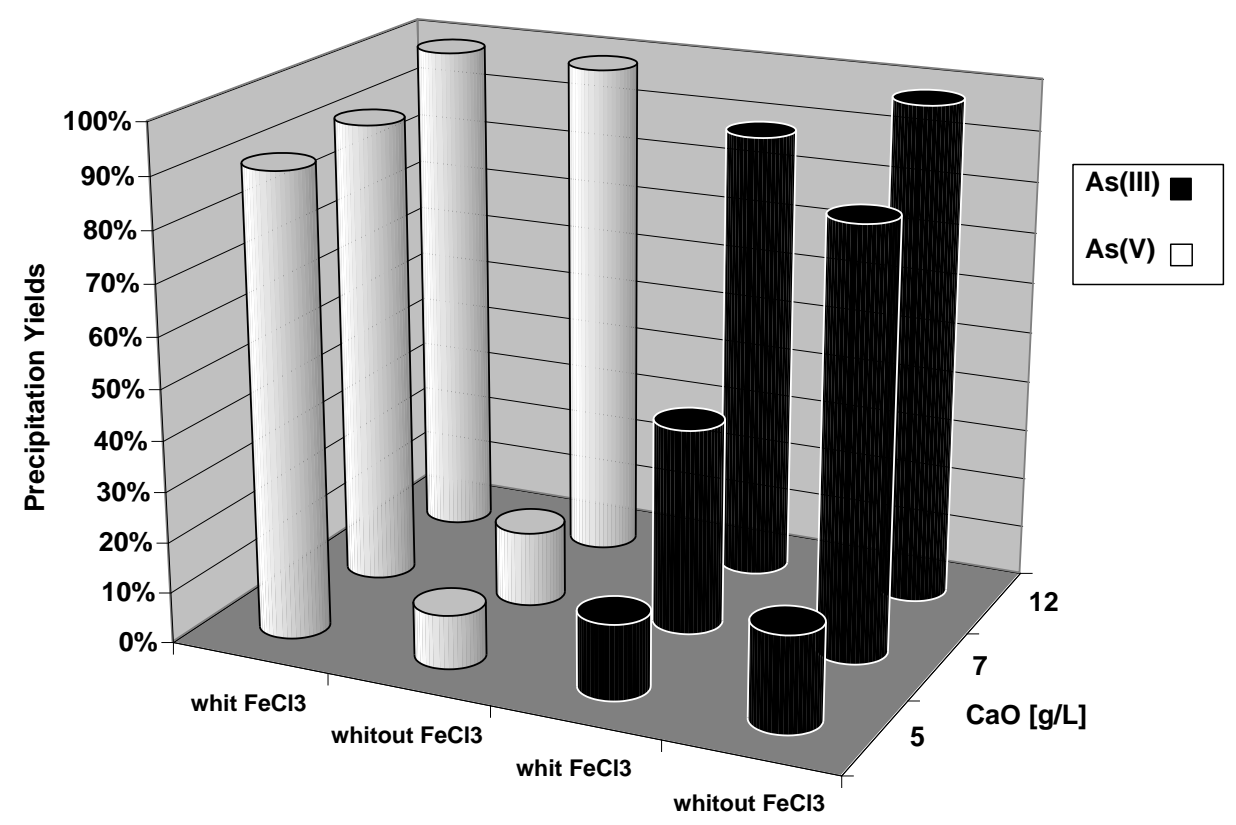

Figure 7. Arsenic precipitation yields after $2 \mathrm{~h}$ : comparison of treatments carried out with and without ferric chloride with the same $\mathrm{CaO}$ concentration.

On the contrary, the coagulant is able to increase the removal of $\mathrm{As}(\mathrm{V})$. As a matter of fact, in treatment $9\left(5 \mathrm{~g} \mathrm{~L}^{-1}\right.$ of $\mathrm{CaO}$ ) the removal yield is only $10 \%$ (As $895 \mathrm{mg} \mathrm{L}^{-1}$ ), whereas in the corresponding treatment 20 this value increases up to $90 \%\left(95 \mathrm{mg} \mathrm{L}^{-1}\right)$. It is possible to conclude that $\mathrm{FeCl}_{3}$ has a double effect: it improves the kinetics of $\mathrm{As}(\mathrm{V})$ precipitation and decreases the precipitation of As(III). As regards acidic tests, the following conclusions can be drawn:

- $\quad \mathrm{As}(\mathrm{III})$ and $\mathrm{As}(\mathrm{V})$ removal becomes significant $(>80 \%)$ when $\mathrm{CaO}$ concentration is greater than $7 \mathrm{~g} \mathrm{~L}^{-1}$ and $10 \mathrm{~g} \mathrm{~L}^{-1}$, respectively;

- $\quad \operatorname{As}(V)$ shows slow kinetics with respect to the As(III) one. This means that the process time required to obtain high $\mathrm{As}(\mathrm{V})$ removal yields is higher than that necessary for the same yield of As(III);

- $\quad$ in the best operating conditions investigated in this work the As removal yield is about $99 \%$ for both arsenic valences;

- $\mathrm{FeCl}_{3}$ reduces the initial solubility of $\mathrm{As}(\mathrm{III})$ but, at the same time, reduces the kinetics of As(III) precipitation. This effect produces an increase of As concentration at the end of the process and consequently the removal yield decreases $(<90 \%)$;

- $\quad \mathrm{FeCl}_{3}$ promotes precipitation kinetics of $\mathrm{As}(\mathrm{V})$ : after $2 \mathrm{~h}$ the precipitation yield is greater than $90 \%$ for each treatment. This is due to formation of scorodite, that has a very low solubility in aqueous solution. XRD analysis confirmed this hypothesis, since the precipitate was mainly represented by such compound. 


\section{Macrothink}

\subsection{Neutral Tests}

Precipitation tests of arsenic in aqueous solution were performed by addition of $\mathrm{CaO}$ at $80^{\circ} \mathrm{C}$. Table 5 shows the real initial concentration of $\mathrm{As}(\mathrm{III})$ and $\mathrm{As}(\mathrm{V})$, the concentration of $\mathrm{CaO}$ as well as the $\mathrm{CaO} / \mathrm{As}$ ratio. In this study the new tests were numbered in succession.

Table 5. Experimental conditions of neutral tests carried out without addition of $\mathrm{FeCl}_{3}$; temperature $80^{\circ} \mathrm{C}$

\begin{tabular}{|c|c|c|c|c|c|}
\hline Treatment & As ion & As, $\mathrm{mg} \mathrm{L}^{-1}$ (measured) & $\mathrm{CaO}, \mathrm{g} \mathrm{L}^{-1}$ & $\mathrm{~g} \mathrm{CaO} / \mathrm{g} \mathrm{As}$ & $\mathrm{pH}(2 \mathrm{~h})$ \\
\hline 25 & As (III) & 340 & 0 & \begin{tabular}{|l|}
0.0 \\
\end{tabular} & 5.59 \\
\hline 26 & As (III) & 340 & 0.5 & 1.5 & 10.28 \\
\hline 27 & As (III) & 340 & 1 & 2.9 & 11.26 \\
\hline 28 & As (III) & 340 & 2 & 5.9 & 11.50 \\
\hline 29 & As (III) & 340 & 5 & 14.7 & 11.65 \\
\hline 30 & As $(\mathrm{V})$ & 10215 & 0 & 0 & 1.41 \\
\hline 31 & As $(\mathrm{V})$ & 10215 & 0.2 & 0.02 & 1.51 \\
\hline 32 & As $(\mathrm{V})$ & 10215 & 0.5 & 0.05 & 1.54 \\
\hline 33 & As $(\mathrm{V})$ & 10215 & 1 & 0.1 & 1.67 \\
\hline 34 & As (V) & 10215 & 5 & 0.5 & 2.52 \\
\hline 35 & As $(\mathrm{V})$ & 10215 & 10 & 1 & 4.38 \\
\hline 36 & As $(\mathrm{V})$ & 10215 & 12 & 1.2 & 4.53 \\
\hline 37 & As $(\mathrm{V})$ & 10215 & 15 & 1.5 & 4.75 \\
\hline 38 & As $(\mathrm{V})$ & 10215 & 40 & 4 & 11.45 \\
\hline
\end{tabular}

$\mathrm{pH}$ of reference samples (treatments 25 and 30) is 6.50 and 1.35 , respectively. The other $\mathrm{pH}$ values are not reported here. This means that $\mathrm{As}_{2} \mathrm{O}_{5}$ shows acid behaviour with respect to $\mathrm{As}_{2} \mathrm{O}_{3}$. In fact, after 5 minutes with $5 \mathrm{~g} \mathrm{~L}^{-1}$ of $\mathrm{CaO}$ the $\mathrm{pH}$ increment is 5 for $\mathrm{As}(\mathrm{III})$ and 1.1 for $\mathrm{As}(\mathrm{V}) . \mathrm{pH}$ is rather constant for nearly all tests and the equilibrium value is already reached after 5 minutes. In treatment 35 the equilibrium value is achieved after $1 \mathrm{~h}$. Equilibrium pHs range from 10 to 12 in treatments 26-29 and from 2.5 to 5 in treatments 34-37. $\mathrm{pH}$ of treatments 31-33 does not change with respect to the value of the control sample, whereas $\mathrm{pH}$ of treatment 38 is around 12.

Figures 8 and 9 show the concentration trend of $\mathrm{As}(\mathrm{III})$ and $\mathrm{As}(\mathrm{V})$, respectively. The reference sample having $0 \mathrm{~g} \mathrm{~L}^{-1}$ of $\mathrm{CaO}$ highlights that the solubility of As(III) decreases during the test (Fig.8), as well as that one of As(V) (see Fig.9). Moreover, the initial precipitation kinetics of $\mathrm{As}(\mathrm{III})$ does not depend on $\mathrm{CaO}$ concentration and the process kinetics of $\mathrm{As}(\mathrm{V})$ increases with the amount of $\mathrm{CaO}$. 


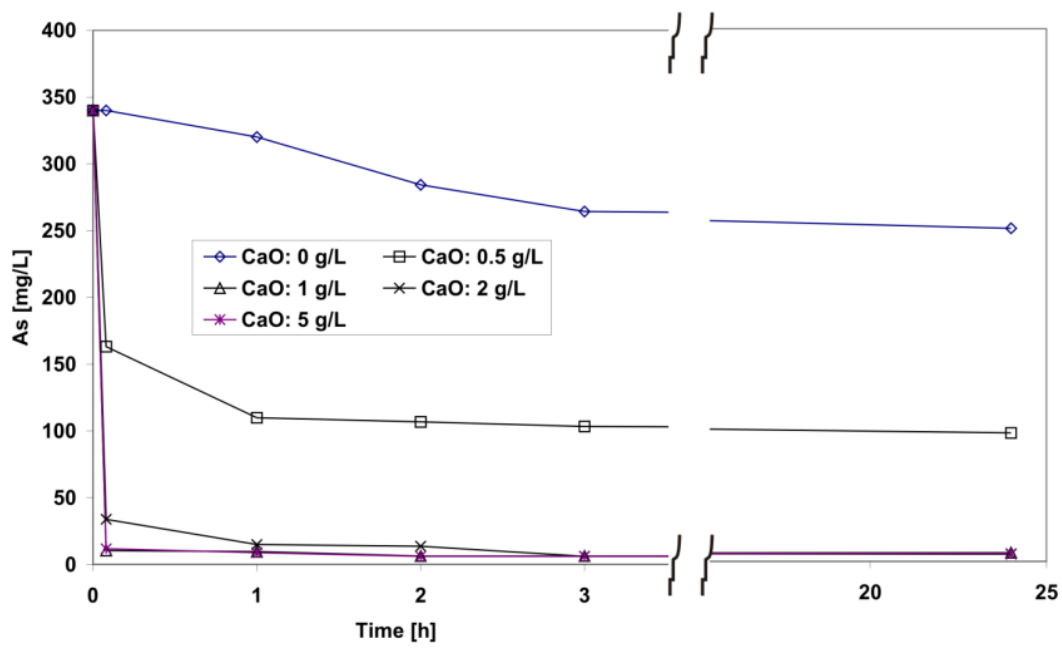

Figure 8. As(III) concentration vs time (treatments 25-29 in Table 5: reference value $0 \mathrm{~g}$ $\mathrm{L}^{-1}$ of $\left.\mathrm{CaO}\right)$.

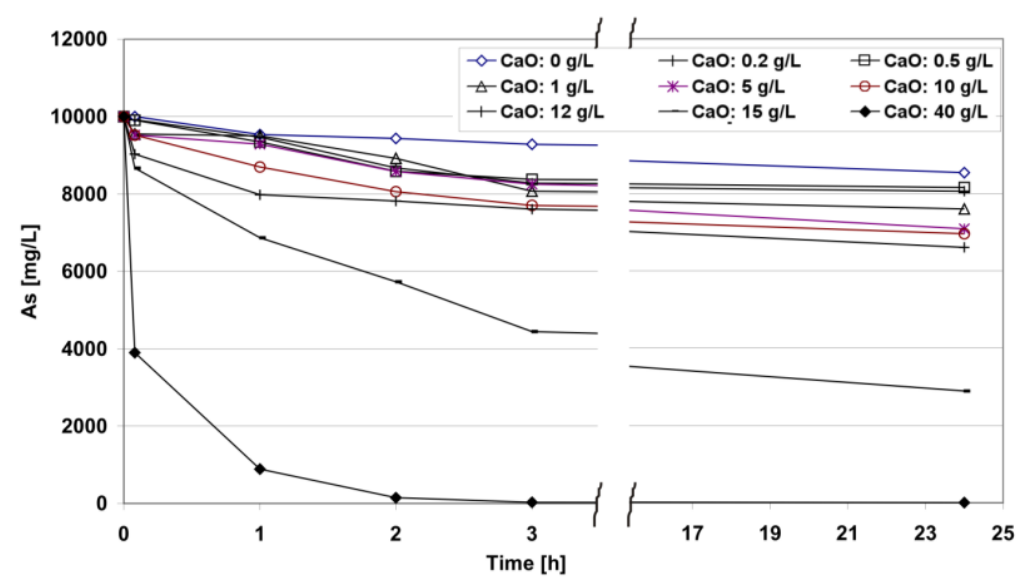

Figure 9. As(V) concentration vs time (treatments 30-38 in Table 5; reference value $0 \mathrm{~g}$ $\mathrm{L}^{-1}$ of $\mathrm{CaO}$, dotted line).

These trends show that it is possible to achieve precipitations greater than $70 \%$ with addition of $\mathrm{CaO}$ only (Ahmed, 2016). Moreover, oxidation of $\mathrm{As}(\mathrm{III})$ to $\mathrm{As}(\mathrm{V})$ seems not to be required, as stated in many of the literature papers. Thus, use of an oxidant that leads to greater operating costs is not required in industrial facilities. Figure 10 shows arsenic precipitation yields at three different process times for each treatment. It is possible to note that after 5 minutes and with a constant amount of $\mathrm{CaO}, \mathrm{As}(\mathrm{V})$ is not removed (only $1 \%$ ), whereas As(III) yield is around 52\% (treatments 26 and 32). This yield increases when $\mathrm{CaO}$ concentration raises. Furthermore, the higher the process time, the greater the precipitation yield. Using the highest concentration of $\mathrm{CaO}\left(5 \mathrm{~g} \mathrm{~L}^{-1}\right)$ in treatments with As(III), the removal is nearly $98 \%$ after $2 \mathrm{~h}$. As( $(\mathrm{V})$ removal with $5 \mathrm{~g} \mathrm{~L}^{-1}$ of $\mathrm{CaO}$ is $14 \%$ only after $2 \mathrm{~h}$ and becomes $29 \%$ after $24 \mathrm{~h}$. This means that a significant $\mathrm{As}(\mathrm{V})$ removal can only be obtained if $\mathrm{CaO}$ concentration is increased to $40 \mathrm{~g} \mathrm{~L}^{-1}$ (treatment 38); these operating conditions assures an As precipitation of $99 \%$ after $2 \mathrm{~h}$ and $100 \%$ after $24 \mathrm{~h}$. 


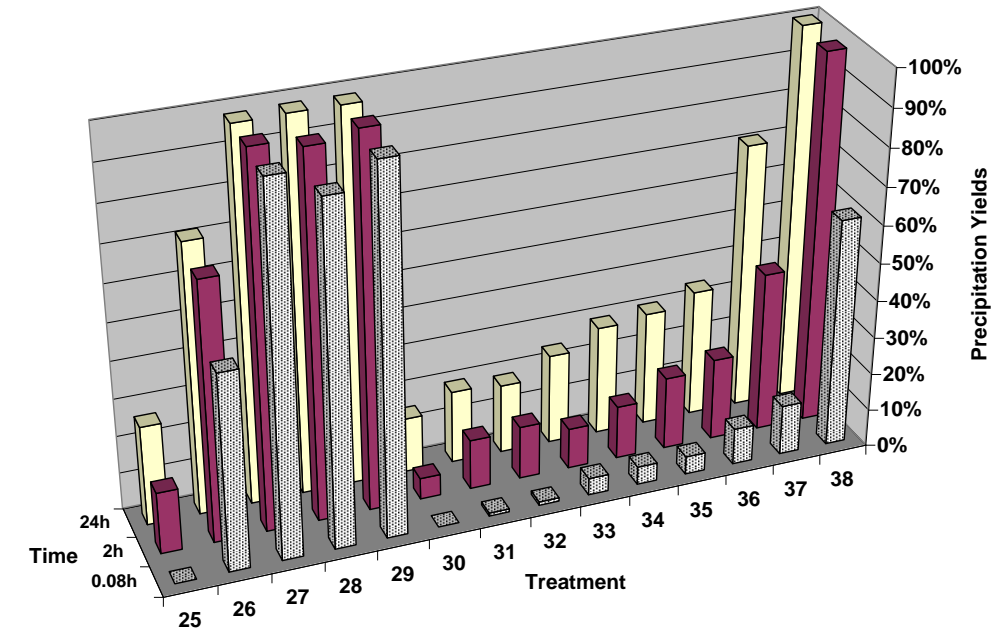

Figure 10. Arsenic precipitation yields at three different process times (treatments 25-38 in Table 5).

Figure 11 shows the arsenic precipitation yields for acid, acid with coagulant and neutral treatments. The most efficient process for As(III) seems to be that one carried out in neutral solution (98\% yield), whereas the best result for $\mathrm{As}(\mathrm{V})$ was obtained in the process carried out by the acid solution with coagulant (90\%). From the results it can be inferred that $\mathrm{Fe}^{3+}$ ions enhance the precipitation of $\mathrm{As}(\mathrm{V})$ because of scorodite formation, according to the reaction:

$$
\mathrm{AsO}_{4}{ }^{3-}+\mathrm{Fe}^{3+}+2 \mathrm{H}_{2} \mathrm{O} \rightarrow \mathrm{FeAsO}_{4} \cdot 2 \mathrm{H}_{2} \mathrm{O} \downarrow
$$

Scorodite has a very low solubility, since the solubility product $K_{\mathrm{sp}}$ is $10^{-24}$. A secondary reason could be the formation of electrostatic binding of soluble arsenic onto the external surface of such coagulant that strongly improves $\mathrm{As}(\mathrm{V})$ precipitation. Figures $12 \mathrm{a}$ and $12 \mathrm{~b}$ show the solubility of the species which are part of the investigated aqueous system and the predominance areas of solid precipitates that can occur in the same system. Those diagrams were developed by Hydra-Medusa software package, specific to draw chemical equilibrium diagrams.

Regarding As(III), the different behaviour obtained with respect to As(V) could be due to deprotonation reaction: after being dissolved in water, $\mathrm{FeCl}_{3}$ gives the hexaaquo iron(III) ion in solution, which would react as follows:

$$
\begin{gathered}
\mathrm{FeCl}_{3} \rightarrow \mathrm{Fe}^{3+}+3 \mathrm{Cl}^{-} \\
{\left[\mathrm{Fe}\left(\mathrm{H}_{2} \mathrm{O}\right)_{6}\right]^{3+}+\mathrm{H}_{2} \mathrm{O} \leftrightarrow\left[\mathrm{Fe}\left(\mathrm{H}_{2} \mathrm{O}\right)_{5}(\mathrm{OH})\right]^{2+}+\mathrm{H}_{3} \mathrm{O}^{+}} \\
{\left[\mathrm{Fe}\left(\mathrm{H}_{2} \mathrm{O}\right)_{5}(\mathrm{OH})\right]^{2+}+\mathrm{H}_{2} \mathrm{O} \leftrightarrow\left[\mathrm{Fe}\left(\mathrm{H}_{2} \mathrm{O}\right)_{4}(\mathrm{OH})_{2}\right]^{+}+\mathrm{H}_{3} \mathrm{O}^{+}}
\end{gathered}
$$

Salts from transition metals form hydrated ions in aqueous solution: hence, the presence of $\mathrm{H}_{3} \mathrm{O}^{+}$ions makes the solution acidic. Additional $\mathrm{H}_{3} \mathrm{O}^{+}$ions are neutralized by $\mathrm{OH}^{-}$coming from $\mathrm{Ca}(\mathrm{OH})_{2}$ : such anions are thus consumed and do not take part to precipitation of As(III) when $\mathrm{pH}$ decreases. Furthermore, precipitation of both As(III) and As(V) in acidic medium is lower with respect to the neutral one since sulphuric acid is completely split in solution: this 
leads to precipitation of $\mathrm{CaSO}_{4} \cdot 2 \mathrm{H}_{2} \mathrm{O}$, so that less $\mathrm{Ca}^{2+}$ ions are available for removal of arsenic.

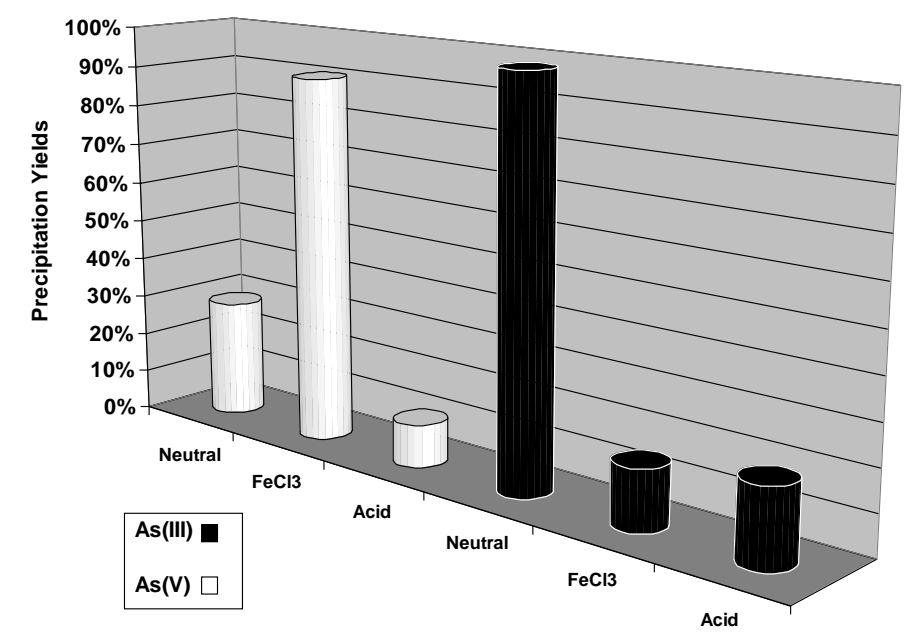

Figure 11. Arsenic precipitation yields after $2 \mathrm{~h}$ : yields of acid, acid with $\mathrm{FeCl}_{3}$ and neutral treatments with the same $\mathrm{CaO}$ concentration $\left(5 \mathrm{~g} \mathrm{~L}^{-1}\right)$.
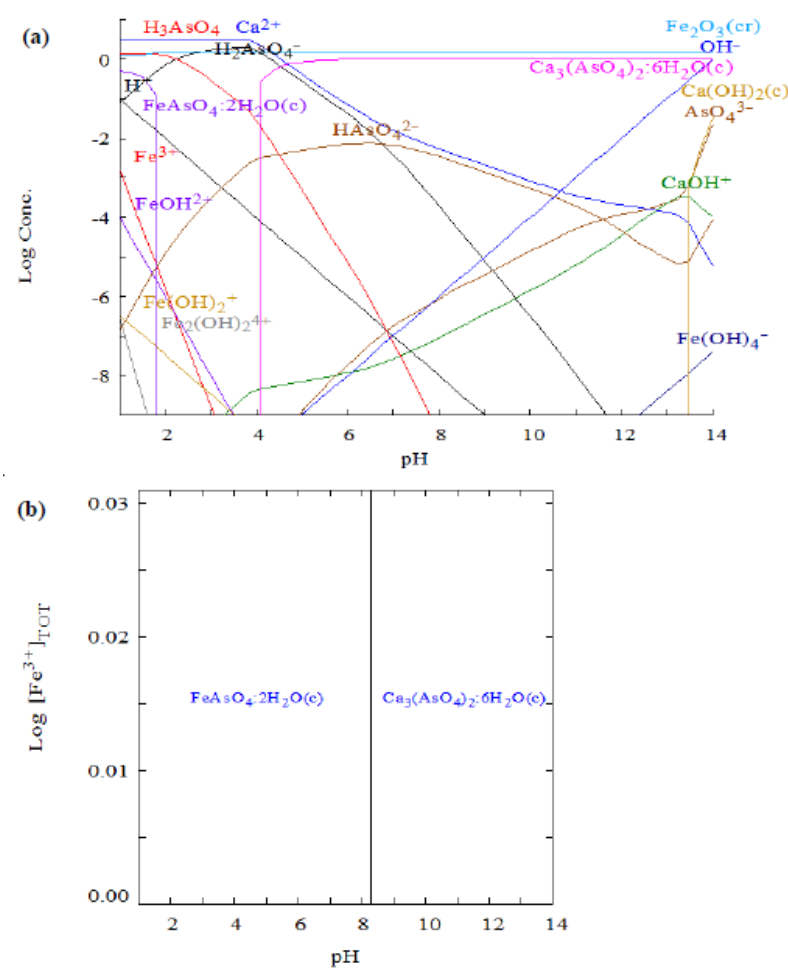

Figure 12). Concentration of salts and ions vs $\mathrm{pH}$ of the aqueous solution investigated (a) and solid precipitates (b)

\section{Conclusions}

In this paper several precipitation tests were carried out to evaluate the best process to remove arsenic from aqueous solutions. The experiments were performed by solutions containing As(III) or As(IV), some of these acidified by sulphuric acid to simulate the 
dissolution of $\mathrm{SO}_{2}$ in treatment of flue gas from roasting processes of sulphide ores. Different amounts of $\mathrm{CaO}$ were added to some solutions, whereas in some experiments iron chloride was also tested to study the influence on As precipitation.

In the acidic tests the initial solubility of $\mathrm{As}(\mathrm{III})$ without $\mathrm{CaO}$ is strongly influenced by $\mathrm{FeCl}_{3}$ : this compound indeed reduces the As(III) solubility and at the same time slows down the kinetics of precipitation when $\mathrm{CaO}$ is added. On the contrary, the precipitation kinetics of $\mathrm{As}(\mathrm{V})$ is improved when iron chloride is added. Without $\mathrm{FeCl}_{3}, \mathrm{As}(\mathrm{III})$ and $\mathrm{As}(\mathrm{V})$ removal becomes significant when $\mathrm{CaO}$ concentration is greater than $7 \mathrm{~g} \mathrm{~L}^{-1}$ and $10 \mathrm{~g} \mathrm{~L}^{-1}$, respectively. In the experiments with iron chloride, a precipitation yield greater than $80 \%$ is obtained with $9 \mathrm{~g} \mathrm{~L}^{-1}$ and $5 \mathrm{~g} \mathrm{~L}^{-1}$ of $\mathrm{CaO}$ for $\mathrm{As}(\mathrm{III})$ and $\mathrm{As}(\mathrm{V})$, respectively. From these results it can be inferred that $\mathrm{FeCl}_{3}$ has a negative effect on $\mathrm{As}(\mathrm{III})$ removal; on the contrary, there is a clear positive effect of $\mathrm{FeCl}_{3}$ on $\mathrm{As}(\mathrm{V})$ removal

Nearly $98 \%$ of $\mathrm{As}(\mathrm{III})$ was removed with $10 \mathrm{~g} \mathrm{~L}^{-1}$ of $\mathrm{CaO}$ after 15 minutes, whereas $12 \mathrm{~g} \mathrm{~L}^{-1}$ are necessary to remove $95 \%$ of arsenic after $2 \mathrm{~h}$ when $\mathrm{FeCl}_{3}$ is added.

$99 \%$ of $\mathrm{As}(\mathrm{V})$ is removed with $10 \mathrm{~g} \mathrm{~L}^{-1}$ of $\mathrm{CaO}$ after 45 minutes, with or without iron chloride; however, when iron chloride is present, $5 \mathrm{~g} \mathrm{~L}^{-1}$ of $\mathrm{CaO}$ and 45 minutes are enough to remove about $90 \%$ of $\mathrm{As}(\mathrm{V})$.

Sulphuric acid has shown a positive effect on $\mathrm{As}(\mathrm{V})$ removal; in fact, in the neutral experiments $40 \mathrm{~g} \mathrm{~L}^{-1}$ of $\mathrm{CaO}$ and $1 \mathrm{~h}$ are necessary to precipitate $90 \%$ of As. The same yield is obtained for $\mathrm{As}(\mathrm{III})$ with only $5 \mathrm{~g} \mathrm{~L}^{-1}$ of $\mathrm{CaO}$ after 5 minutes.

When comparing the acid and neutral series of tests, it can be highlighted that the medium in which As is dissolved influences the precipitation process: in fact, As(III) precipitation is much more efficient in neutral conditions, i.e. in water without sulphate ions. Moreover, iron chloride improves $\mathrm{As}(\mathrm{V})$ removal but reduces that one of As(III). This research is a preliminary work that will help in designing and implementing the treatment of wet scrubbing wastewater from the flue gas of the roasting pilot-plant that will be constructed in the next months.

\section{References}

Ahmed, F. (2016). Arsenic mitigation technologies in South and East Asia, World Bank Technical Report, http://siteresources.worldbank.org/INTSAREGTOPWATRES/Resources/ArsenicVolII_PaperI II.pdf.

Bhattacharyya, D., Jumawan, A. B., Sun, G., Sund-Hagelberg, C., \& Schwitzgebel, K. (1980). Precipitation of heavy metals with sodium sulphide: bench-scale and full scale experimental results. AIChE Symposium Series, 209, 31-38.

Bothe, J. V., \& Brown, P. W. (1999). Arsenic immobilization by calcium arsenate formation. Environ Sci Technol, 33, 3806-3811. http://dx.doi.org/10.1021/es980998m

Camacho, J., Wee, H. Y., \& Kramer, T. A. (2009). Autenrieth R. Arsenic stabilization on 
water treatment residuals by calcium addition. J Hazard Mater, 165, 599-603.

http://dx.doi.org/10.1016/j.jhazmat.2008.10.038

Cornelis, G., Poppe, S., Van Gerven, T., Van Den Broeck, E., Ceulemans, M., \& Vandecasteele, C. (2008). Geochemical modelling of arsenic and selenium leaching in alkaline water treatment sludge from the production of non-ferrous metals. J Hazard Mater, 159, 271-279. http://dx.doi.org/10.1016/j.jhazmat.2008.02.016

Guenegou, T., Tambuté. A., Jardy, A., \& Caude, M. (1997). Elimination of effluent arsenic resulting from hydrolysis of Lewisites. Analusis, 25, 279-286.

Gulledge, J. H., \& O'Connor, J. H. (1973). Removal of As(V) from water by adsorption on aluminium and ferric hydroxide. J Am Water Works, 65, 548-552.

Harper, T. R., \& Kingham, N. W. (1992). Removal of arsenic from wastewater using chemical precipitation methods. Water Environ Res, 64, 200-203.

http://dx.doi.org/10.2175/WER.64.3.2

Hering, J. G., Chen, P., Wilkie, J., Elimelch, M., \& Liang, S. (1996). Arsenic removal by ferric chloride. J Am Water Works, 88, 155-167.

Kundu, S., \& Gupta, A. K. (2008). Immobilization and leaching characteristics of arsenic from cement and/or lime solidified/stabilized spent adsorbent containing arsenic. J Hazard Mater, 153, 434-443. http://dx.doi.org/10.1016/j.jhazmat.2007.08.073

Martínez-Villegas, N., Briones-Gallardo, R., Ramos-Leal, J. A., Avalos-Borja, M., Castañón-Sandoval, A. D., Razo-Flores, E., \& Villalobos, M. (2013). Arsenic mobility controlled by solid calcium arsenates: A case study in Mexico showcasing a potentially widespread environmental problem. Environ Pollut, 176, 114-122.

http://dx.doi.org/10.1016/j.envpol.2012.12.025

Moon, D. H., Dermatas, D., \& Menounou, N. (2004). Arsenic immobilization by calcium-arsenic precipitates in lime treated soils. Sci Total Environ, 330, 171-185. http://dx.doi.org/10.1016/j.scitotenv.2004.03.016

Namasivayam, C., \& Senthil, K. S. (1998). Removal of arsenic(V) from aqueous solutions using industrial solid waste: adsorption rates and equilibrium studies. Ind. Eng Chem Res, 37, 4816-4822. http://dx.doi.org/10.1021/ie970774x

Palfy, P., Vircikova, E., \& Molnar, L. (1999). Processing of arsenic waste by precipitation and solidification. Waste Manage, 19, 55-59. http://dx.doi.org/10.1016/S0956-053X(99)00014-8

Reese, R. G. (2016). U.S. Geological Survey Mineral Commodity Summaries. [Online] Available: http://minerals.usgs.gov/minerals/pubs/commodity/arsenic

Sadiq, M. (1997). Arsenic Chemistry in Soils: An Overview of Thermodynamic Predictions and Field Observations. Water Air Soil Poll, 93, 117-136.

http://dx.doi.org/10.1007/BF02404751

Salzsauler, K. A, Sidenko, N. V., \& Sherriff, B. L. (2005). Arsenic mobility in alteration 
products of sulfide-rich, arsenopyrite-bearing mine wastes, Snow Lake, Manitoba, Canada. Appl Geochem, 20, 2303-2314. http://dx.doi.org/10.1016/j.apgeochem.2005.06.007

Singhania, S., Wang, Q., Filippou, D., \& Demopoulos, G. P. (2005). Temperature and seeding effects on the precipitation of scorodite from sulfate solutions under atmospheric-pressure conditions. Metall Mater Trans B, 36, 327-333. http://dx.doi.org/10.1007/s11663-005-0062-8

Sturgill, J. A, Swartzbaugh, J. T., \& Randall, P. M. (2000). Pollution prevention in the semiconductor industry through recovery and recycling of gallium and arsenic from GaAs polishing wastes. Clean Prod Process, 2, 18-27. http://dx.doi.org/10.1007/s100980050047

Tokunaga, S., Yokoyama, S., \& Wasay, S. A. (1999). Removal of As(III) and As(V) ions from aqueous solution with lanthanum(III) salt and comparison with aluminium(III), calcium(II), and iron(III) salts. Water Environ Res, 71, 299-306.

http://dx.doi.org/10.2175/106143098X121833

Viñals, J., Sunyer, A., Molera, P., Cruells, M., \& Llorca, N. (2010). Arsenic stabilization of calcium arsenate waste by hydrothermal precipitation of arsenical atroalunite. Hydrometallurgy, 104, 247-259. http://dx.doi.org/10.1016/j.hydromet.2010.06.013

Wang, T., Wang, J., Tang, Y., Shi, H., \& Ladwig, K. (2009). Leaching characteristics of arsenic and selenium from coal fly ash: role of calcium. Energy Fuel, 23, 2959-2966. http://dx.doi.org/10.1021/ef900044w

Winkel, L. H. E., Casentini, B., Bardelli, F., Voegelin, A., Nikolaidis, N. P., \& Charlet, L. (2013). Speciation of arsenic in Greek travertines: Co-precipitation of arsenate with calcite. Geochim Cosmochim Acta, 106, 99-110. http://dx.doi.org/10.1016/j.gca.2012.11.049

Yang, L., Donahoe, R. J., \& Redwine, J. C. (2007). In situ chemical fixation of arsenic-contaminated soils: An experimental study. Sci Total Environ, 387, 28-41.

http://dx.doi.org/10.1016/j.scitotenv.2007.06.024

Yuhu, L., Zhihong, L., Qihou, L., Zhongwei, Z., Zhiyong, L., \& Li, Z. (2011). Removal of arsenic from Waelz zinc oxide using a mixed $\mathrm{NaOH}-\mathrm{Na}_{2} \mathrm{~S}$ leach. Hydrometallurgy, 108, 165-170. http://dx.doi.org/10.1016/j.hydromet.2011.04.002

\section{Copyright Disclaimer}

Copyright for this article is retained by the author(s), with first publication rights granted to the journal.

This is an open-access article distributed under the terms and conditions of the Creative Commons Attribution license (http://creativecommons.org/licenses/by/3.0/). 